of the umbilicus; the latter closed. Septa approximate, sutures forming a sharply-bent, forwardly-directed lobe after

Fig. 9.
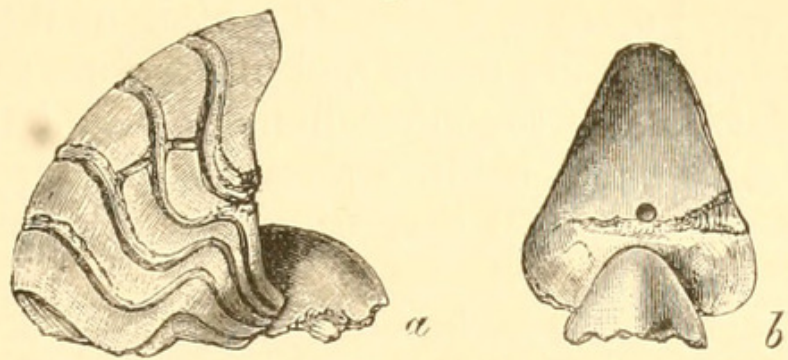

Nautilus (Hercoglossa) Cassinianus.- $a$, lateral view of a fragment, showing the curvature of the sutures ; $b$, front view, showing the position of the siphuncle. Drawn from a specimen in the British Museum (no. 71003). Natural size.

leaving the umbilicus, then bent backwards in a similar lobe, and finally directed forwards towards the periphery, which they cross with a narrow arch. Siphuncle situated below the centre.

Remarks. This species closely resembles Nautilus (Hercoglossa) danicus, but is easily distinguished by its more conepressed whorls and the position of its siphuncle. It may be added that the close proximity of these species in the geological series $(N .(H$.$) danicus from the uppermost beds of$ the Chalk, and $N$. (H.) Cassinianus from the Lower Eocene) renders their near relationship highly probable.

The name of this species is taken from a list of the Edwards Collection of Fossils now in the British Museum, but the species was never described. Edwards erroneously placed it in the genus Aturia.

Horizon. London Clay (Lower Eocene).

Localities. Finchley, Middlesex (Edwards's type); Isle of Sheppey.

L.-Further Descriptions of new Coleoptera of the Family Scarabæidæ in the British Museum. By Charles O. W ATERHOUSE.

Since my last paper was written (suprè, p. 365) I have, by the kindness of Mr. D. Sharp, been able to examine the type specimens of the species of Gymnopleurus described by him. I think that in this genus, as in so many other Coprophaga, there are two forms of males, a major and a minor form, the major form having the anterior tibiæ more inflexed at the apex and the posterior angles of the thorax Ann.\& Mag. N. Hist. Ser. 6. Vol. v. 
more dilated than in the minor form, which more approaches the female. The series of $G$. sinuatus and $G$. assamensis in the British-Museum Collection show this I think very distinctly. I believe the species of this group described by $\mathrm{Mr}$. Sharp are all good species, except $G$. calcar and $G$. celebicus, which, in my opinion, are major and minor forms of the same species; G. dubius, on the other hand, which has been considered the female of $G$. calcar by von Harold, appears to me to be possibly distinct, or it may be merely a large female.

\section{Gymnopleurus Hornei.}

Oblongus, subparallelus, parum convexus, niger; thorace fortiter reticulato-foveolato; elytris surdis, coriaceis, striatis, interstitiis maculis parvis irregularibus parum elevatis nitidis ornatis. Long. $4 \frac{2}{3}$ lin.

Hab. N.W. India (C. Horne, Esq.).

Allied to G. flagellatus, F., but smaller and rather more parallel. The head is of the same form, triangularly incised in front, closely foveolate-punctate posteriorly. The thorax is less broad, more rounded at the hind angles, marked with closely placed dull foveæ, which are irregular in size, but are relatively larger than in G. flagellatus, so that the interspaces are generally very narrow and form a sort of shining network; each fovea has a minute shining tubercle in its centre. The elytra are dull, finely coriaceous, striated as in G. flagellatus, the interstices having a series of small, very irregular, slightly raised, shining spots, somewhat as in Silpha rugosa; metasternum more coarsely foveolate than in G. flagellatus; lateral exposed margin of the abdomen not carinate.

\section{Gymnopleurus singularis.}

Oblongus, parum convexus, supra obscure cupreus, surdus, subtus niger, nitidus; thorace subtilissime coriaceo, sat crebre subtiliter punctato, lateribus medio angulatis dein paulo sinuatis, angulis posticis obtusis paulo retrorsum productis; elytris subtilissime coriaceis, striatis, interstitiis guttis minutis nitidis crebre aspersis. Long. $8 \frac{1}{2}$ lin.

Hab. Corea (Sir E. Belcher).

Closely allied to $G$. sinuatus, of a dull coppery colour shaded with black, and with a silky appearance. The back part of the head is dull, coriaceous, with minute asperate punctures. Thorax very finely but distinctly punctured, the punctures separated generally by three or four diameters of a puncture, the punctures towards the sides appearing slightly asperate. The sides are distinctly but obtusely angular at 
the middle, and immediately behind this angulation there is a slight but distinct sinuosity; from this point to the base the sides are gently curved inwards and the margins are thickened; the posterior angles are slightly produced backwards, the produced part obtusely rounded. The elytra are finely coriaceous, distinctly striated, the striæ indistinctly punctured, the interstices flat, with rather closely placed, minute, shining: dots. The metasternum has an impressed median line, which widens out into a somewhat deep impression posteriorly; the anterior part is slightly swollen in the middle; the sloping sides with shining granules.

This species is very close to G. maurus, Sharp; but that species is black and has the sides of the thorax more distinctly angular.

\section{Gymnopleurus assamensis.}

Parum convexus, supra cupreus, subtus cupreo-niger, parum nitidus ; thorace subtiliter coriaceo, punctis parvis sat crebre asperso, ante medium oblique angustato, postice subparallelo, angulis postice rectangularibus, sat obtusis ; elytris tenuiter striatis, striis punctis minutis haud approximatis instructis, interstitiis subtilissime coriaceis et crebre tenuiter nitido-granulosis ; antennis ferrugineoflavis, basi nigris.

Long. $6 \frac{1}{2}-10$ lin.

Hab. N.W. India, Sylhet, Assam, Corea.

This species is well known in collections under the above name, but does not appear to have been described. It closely resembles G. sinuatus, but is coppery in colour and more finely sculptured, and consequently is less dull; the sides of the thorax are more distinctly angular.

\section{Gymnopleurus brahminus.}

Niger, opacus, supra omnino æqualiter subtiliter granulosus; thorace ante medium oblique angustato, postice perparum angustiore fere parallelo, angulis posticis vix prominulis; elytris leviter striatis.

Long. $9 \frac{1}{2}$ lin.

\section{Hab. China (J. C. Bowring, Esq.).}

This species is close to G. sinuatus, but is quite black and dull and differently sculptured. The thorax is obtusely angular at the middle of the sides, scarcely narrowed towards the base, almost parallel, with the posterior angles less prominent than in G. sinuatus, but a little more so than in $G$. melanarius, the angles themselves obliquely rounded off. 
The surface is evenly and closely covered with minute, but distinct round or oval depressed granules, and is without punctures. The elytra have the surface extremely finely coriaceous, and covered with minute but distinct round granules, which are a trifle smaller than those on the thorax, and not quite so crowded, so that the coriaceous surface is visible in the very narrow interspaces. The anterior part of the metasternum is a little more sloping than in $G$. sinuatus, and although slightly convex, there is no distinct swelling in the middle.

\section{Megathopa cupreicollis.}

Oblongo-ovalis, convexus, cupreo-æneus; capite antice rugato, nigro, vertice sat fortiter punctato; thorace nitido, parum sericeo, subtilissime punctulato; elytris nigro-cyaneis, parum nitidis, sericeo-coriaceis, basi angustatis, convexis, distincte striato-punctatis, interstitiis planis, guttis minutissimis nitidis crebre aspersis ; pygidio fortiter sat crebre punctato.

Long. 7 lin.

\section{Hab. Peru.}

The punctures on the vertex of the head are strong and rather close together. The thorax has the posterior angles even more obliquely rounded than is usual; the punctures are extremely fine but moderately distinct, moderately near together; with a strong magnifying-glass, very minute punctures may be seen in the intervals. The elytra are much narrowed at the base, moderately convex, with lines of very distinct, moderately closely placed punctures, with scarcely any trace of striæ. The pygidium is obscure green, with rather strong dark punctures, which are separated from each other by one to one and a half diameters; metasternum apparently impunctate in the middle, with strong punctures at the sides; antennæ pale ferruginous.

This species has the sides of the thorax gently sinuate in front of the middle, as in $M$. bicolor, with a projection in front of it, the projecting part itself gently sinuate.

\section{Megathopa virens, Harold, var.?}

Oblongo-ovalis, minus convexus, nitidus, nigro-cæruleus; capite vertice punctato, antice rugato; thorace lævi, lateribus medio angulatis, impressis; elytris subtilissime rugosis, fere lævibus, lævissime striatis, striis impunctatis, interstitiis planis; pygidio basi lævissimo, dimidio apicali confertim rugoso-punctato, flavopubescente.

Long. $9 \frac{1}{2}$ lin.

Hab. Brazil? 
This is the smoothest species known to me; the thorax has the sides distinctly but obtusely angular and impressed, without any projection before the front angles, the angles themselves slightly acute and diverging; the elytra have the striæ scarcely noticeable, except at the apex; the metasternum is entirely smooth, including the sides.

\section{Megathopa aneicollis.}

Oblongus, convexus, sat nitidus, æneus, piceo-tinctus ; capite postice punctato, medio læviore, antice rugato; thorace medio lævi, lateribus et basi sat fortiter punctatis, lateribus medio angulatis, impressis, angulis anticis fere rectis; elytris minus nitidis, sat fortiter striatis, striis punctatis, interstitiis leviter convexis, subtilissime coriaceis piceo ænoque mutantibus; stria octava basi cariniformi ; pygidio piceo, fortiter punctato ; metasterno medio lævi, ad latera et antice fortiter parce punctato. Long. $6 \frac{1}{2}$ lin.

Hab. Brazil.

This species is allied to $M$. columbica, Harold, but has the sides of the thorax strongly punctured.

\section{BIBLIOGRAPHICAL NOTICE.}

Memoir on the Anatomy of the Humpback Whate (Megaptera longimana, Rudolphi). Вy John Struthers, M.D. Edinburgh : Maclachlan \& Stewart, 1889.

Is this volume Prof. Struthers gives us the various observations * he made on the anatomy of the male Humpback Whale, 40 feet in length, which for five or six weeks disported itself in the Tay, at the end of 1883. The proximity of experienced whalers in Dundee, however, at length proved fatal to the interesting cetacean, as it fed on the young herrings and sprats, and other pelagic forms in the estuary. It was harpooned on the last day of December, but in no vital part, since the harpoons struck too high, and after a chase of twentyone hours, in which it exhibited remarkable strength and endurance, the lines parted on the morning of 1st January and it was free. Shock, loss of blood, and the exhaustion of the chase, for it dragged for a time a steam-tug, a steam-launch, and two rowing-boats, proved too much for it, and it would seem to have died shortly afterwards without again venturing into St. Andrews Bay, otherwise the destination of the skeleton might have been different.

* Which appeared in the 'Journal of Anatomy and Physiology', 1887-1889. 


\section{$2 \mathrm{BHL}$ Biodiversity Heritage Library}

Waterhouse, Charles Owen. 1890. "L.-Further descriptions of new Coleoptera of the family Scarabæidæ in the British Museum." The Annals and magazine of natural history; zoology, botany, and geology 5, 409-413. https://doi.org/10.1080/00222939009460851.

View This Item Online: $\underline{\text { https://www.biodiversitylibrary.org/item/88001 }}$

DOI: https://doi.org/10.1080/00222939009460851

Permalink: https://www.biodiversitylibrary.org/partpdf/64904

\section{Holding Institution}

Smithsonian Libraries

\section{Sponsored by}

Smithsonian

\section{Copyright \& Reuse}

Copyright Status: Public domain. The BHL considers that this work is no longer under copyright protection.

This document was created from content at the Biodiversity Heritage Library, the world's largest open access digital library for biodiversity literature and archives. Visit BHL at https://www.biodiversitylibrary.org. 